Jurnal Hukum Saraswati (JHS),Volume. 03, Nomor 02, (2021)

FAKULTAS HUKUM UNMAS DENPASAR

ISSN (Cetak) : 2715-758X ISSN (Online): 2720-9555

Doi:https://doi.org/10.36733/jhshs.v2i2

https://e-journal.unmas.ac.id/index.php/JHS

\title{
PEMBENTUKAN MEMORANDUM OF UNDERSTANDING SEBAGAI PENGEMBANGAN SISTEM PEMBELAJARAN DI MASA PANDEMI COVID-19
}

\author{
Oleh : \\ I Wayan Agus Vijayantera ${ }^{1)}$, Ni Komang Ratih Kumala Dewi ${ }^{2)}$ \\ 1)2)Fakultas Hukum Universitas Mahasaraswati Denpasar \\ Email : agus.vije@unmas.ac.id ${ }^{1)}$
}

\begin{abstract}
For educational institutions during the Covid-19 pandemic, in carrying out learning and developing learning systems, they can collaborate with other institutions tobecome resource persons. This learning system can use a Memorandum of Understanding as a basis for cooperation. Based on this, it is interesting to conduct further studies regarding thereasonsfortheneed to form a Memorandum of Understanding in implementing a cooperative-based learning system during the Covid-19 pandemi cand the methodof compiling a Memorandum of Understanding as a legal basis for working together to carry outlearning during the Covid-19 pandemic. In the discussion, the Memorandum of Understanding can be used for educational institutions to cooperate with other institutions in implementing an online learning system by inviting the institutions they invite to cooperate as resourcepersons. A Memorandum of Understanding isused as a basis for cooperation because its for missimpleand its implementation is flexible depending on the communication of the parties regarding the conditions and technical implementation. With regard to drafting a Memorandum of Understanding, the anatomy of a Memorandum of Understanding is more or less the same as the anatomy of an agreement, only that its contents are simpleranddo not regulate in detail because a Memorandum of Understanding is aninitial agreement which later needs to be followedup with a written or oral agreement.
\end{abstract}

Keywords : Memorandum of Understanding, Learning System, Covid-19

\begin{abstract}
Abstrak
Bagi lembaga penyelenggara pendidikan pada masa pandemi covid-19 dalam melaksanakan pembelajaran serta mengembangkan sistem pembelajaran dapat bekerjasama dengan lembaga lain untuk menjadi narasumber. Sistem pembelajaran ini dapat menggunakan Memorandum ofUnderstanding sebagai landasan kerjasama. Berdasarkan hal tersebut, maka menarik untuk melakukan kajian lebih lanjut mengenai alasan dibutuhkannya membentuk Memorandum ofUnderstanding dalam melaksanakan sistem pembelajaran berbasis kerjasama di masa pandemi covid-19 serta Metode menyusun Memorandum of Understanding sebagai dasar hokum bekerjasama melaksanakan pembelajaran di masa pandemi
\end{abstract}


Jurnal Hukum Saraswati (JHS) Volume. 03, Nomor 02, (2021)

FAKULTAS HUKUM UNMAS DENPASAR

ISSN (Cetak) : 2715-758X ISSN (Online): 2720-9555

DOI:https://doi.org/10.36733/jhshs.v2i2

https://e-journal.unmas.ac.id/index.php/JHS

covid-19. Pada pembahasan, Memorandum of Understanding dapat digunakan bagi lembaga pendidikan untuk bekerjasama dengan lembaga lain dalam melaksanakan sistem pembelajaran online dengan mengundang lembaga yang diajak bekerjasama menjadi narasumber. Memorandum of Understanding digunakan sebagai landasan kerjasama karena bentuknya simpel dan pelaksanaannya fleksibel tergantung pada komunikasi para pihak mengenai kondisi dan teknis pelaksanaannya. Berkenaan dengan menyusun Memorandum ofUnderstanding, anatomi dari Memorandum of Understanding kurang lebih sama dengan anatomi perjanjian, hanya saja isinya lebih simpel dan tidak mengatur secara terperinci karena Memorandum ofUnderstandingmerupakan kesepakatan awal yang nantinya perlu ditindaklanjuti dengan perjanjian tertulis maupun lisan.

Kata Kunci : Memorandum of Understanding, Sistem Pembelajaran, Covid-19

\section{PENDAHULUAN}

Virus Corona atau yang dikenal dengan Covid-19 merupakan suatu virus yang dapat mengganggu kesehatan setiap orang yang terjangkit virus ini. Virus ini menyebar dengan sangat cepat hingga ke seluruh dunia sehingga menciptakan suatu kondisi yang disebut dengan pandemi covid19. Penyebaran virus Covid-19 disebut sebagai pandemi karena bagi orang yang tertular virus ini tidak hanya mengakibatkan penderitanya mengalami sakit saja, melainkan dapat berdampak pada kematian. Penyebaran virus corona atau Covid-19 ini melalui pernafasan, sehingga seluruh pemerintah di dunia menghimbau masyarakatnya untuk rajin membersihkan diri terutama dengan rajin mencuci tangan, menggunakan masker, hingga menjaga jarak dengan orang lain. Banyak pula kebijakan lain pemerintah yang ditujukan untuk memutus rantai penyebaran Virus Covid-19, seperti membatasi kegiatan masyarakat, menutup beberapa sektor pekerjaan yang bersifat non essensial dengan memberlakukan sistem WFH(WorkFromHome).

Pandemi Covid-19 membawa pengaruh kepada semua lintas kehidupan, khususnya pendidikan. Akibat dari pademi covid-19, pelaksanaan sekolah dari taman kanakkanak hingga universitas ditutup. UNESCO mengatakan bahwa 300 juta murid terganggu kegiatan sekolahnya dan penutupan sekolah sementara akibat dari kesehatan dan krisis. ${ }^{1}$ Penutupan sekolah bukanlah berarti

1 R. Gilang K. , 2020, Pelaksanaan Pembelajaran Daring di Era Covid-19, Lutfi Gilang, Banyumas, h. 1. 
Jurnal Hukum Saraswati (JHS) Volume. 03, Nomor 02, (2021)

FAKULTAS HUKUM UNMAS DENPASAR

ISSN (Cetak) : 2715-758X ISSN (Online): 2720-9555

DOI:https://doi.org/10.36733/jhshs.v2i2

https://e-journal.unmas.ac.id/index.php/JHS

kegiatan pembelajaran ditiadakan. Kegiatan pembelajaran tetap diadakan walaupun kondisi sekolah ditutup, hanya saja kegiatan pembelajaran dilakukan tidak dengan cara tatap muka. Penutupan sekolah ini secara alamiah memunculkan suatu ide pelaksanaan pembelajaran di tengah masa pandemi Covid-19 yakni pembelajaran dengan cara daring atau memanfaatkan media online. Penutupan sekolah ini hanyalah upaya sementara yang dilakukan untuk memutus rantai penyebaran virus Covid-19, sehingga suatu saat ketika pandemi Covid-19 sudah reda akan memberikan suatu harapan bahwa sekolah akan dapat melakukan pembelajaran tatap muka kembali.

Metode pembelajaran dengan memanfaatkan media online caranya adalah menggunakan fitur aplikasi yang tersedia pada perangkat elektronik seperti handphone, laptop, maupun komputer. Fitur aplikasi yang umum digunakan dalam pembelajaran online seperti aplikasi zoom, webex, googlemeet, dan aplikasi lainnya. Pembelajaran online ini memiliki keunggulan dan kekurangan. Adapun keunggulan pembelajaran dengan cara online adalah :

a. Terjadinya perkembangan jaman sistem pembelajaran dengan memanfaatkan media online;

b. Perkembangan pembelajaran tidak hanya dilakukan di dalam kelas saja;

c. Metode atau cara melakukan pembelajaran mengalami perkembangan;

d. Pemanfaatan media online lebih terbuka dalam mengakses informasi materi pembelajaran.

Pembelajaran dengan cara online juga memiliki beberapa kekurangan seperti berikut :

a. Tidak semua orang mampu memiliki perangkat elektronik yang mendukung pembelajaran online

b. Tidak semua orang mampu memanfaatkan media online

c. Keterbatasan terhadap kuota internet dan sinyal

d. Peserta didik belum tentu belajar dengan serius jika 
Jurnal Hukum Saraswati (JHS) Volume. 03, Nomor 02, (2021)

FAKULTAS HUKUM UNMAS DENPASAR

ISSN (Cetak) : 2715-758X ISSN (Online): 2720-9555

DOI:https://doi.org/10.36733/jhshs.v2i2

https://e-journal.unmas.ac.id/index.php/JHS

95

pembelajaran dilakukan tanpa tatap muka

e. Guru dan/atau dosen dalam mengajar lebih banyak membebankan tugas kepada peserta didik.

Terlepas dari keunggulan dan kekurangan tersebut, untuk melakukan optimalisasi pembelajaran dengan cara online, lembaga pendidikan baik sekolah maupun perguruan tinggi dapat melakukan kerjasama dengan lembaga lain dalam memberikan edukasi kepada peserta didik secara online. Kerjasama dapat dilakukan dengan cara membentuk Perjanjian maupun membentuk Nota Kesepahaman atau dalam istilah lainnya dikenal dengan Memorandum ofUnderstanding (MoU).

Memorandum ofUnderstanding $(\mathrm{MoU})$ atau Nota Kesepahaman merupakan bentuk yang umum digunakan oleh instansi dalam menjalin kerjasama. Memorandum ofUnderstanding (MoU) atau Nota Kesepahaman menjadi landasan umum dalam melaksanakan kerjasama. Dalam kajian hukum, istilah Memorandum ofUnderstanding (MoU) atau Nota Kesepahaman tidak dikenal dalam Kitab Undang-Undang Hukum Perdata. Dalam kategori perjanjian tak bernama sebagai perjanjian yang diatur namanya di luar kitab Undang-Undang Hukum Perdata, istilah Memorandum ofUnderstanding (MoU) atau Nota Kesepahaman masih belum ada aturannya. Memorandum ofUnderstanding (MoU) atau Nota Kesepahaman merupakan suatu kesepakatan yang lahir dalam kebiasaan perdagangan Internasional, dan sering diadaptasi pula dalam kebiasaan-kebiasaan melakukan hubungan bisnis maupun hubungan kerjasama dalam hubungan skala nasional. kekosongan norma yang mengatur dalam hukum nasional mengenai Memorandum ofUnderstanding (MoU) atau Nota Kesepahaman tentunya mempertanyakan terkait metode atau teknis membentuk dan melaksanakan Memorandum ofUnderstanding (MoU) atau Nota Kesepahaman terutama jika digunakan sebagai landasan kerjasama terutama dalam kegiatan pembelajaran online. 
Jurnal Hukum Saraswati (JHS) Volume. 03, Nomor 02, (2021)

FAKULTAS HUKUM UNMAS DENPASAR

ISSN (Cetak) : 2715-758X ISSN (Online): 2720-9555

DOI:https://doi.org/10.36733/jhshs.v2i2

https://e-journal.unmas.ac.id/index.php/JHS

96

Berdasarkan hal tersebut, maka menarik dilakukan penelitian dengan judul "Pembentukan Memorandum OfUnderstanding

Sebagai

Pengembangan Sistem Pembelajaran

Di Masa Pandemi Covid-19” dengan menganalisis beberapa permasalahan terkait alasan dibutuhkannya membentuk Memorandum

ofUnderstanding dalam melaksanakan sistem pembelajaran berbasis kerjasama di masa pandemi covid-19 serta Metode menyusunMemorandum ofUnderstandingsebagaidasarhukumbe kerjasamamelaksanakanpembelajarand i masa pandemi covid-19.

\section{B. METODE PENELITIAN}

Metode

yangdigunakandalampenelitianiniadala hpenelitianhukumnormatif.

Penelitianhukumnormatifmerupakanpe nelitiankepustakaan. Bahanhukum yang

dipergunakanmeliputiberbagaiperatura nperundang - undangan, buku, karyailmiah yang berkaitandengantopikpenelitian.

Menurut Peter Mahmud Marzuki, penelitianhukumnormatifadalahsuatu proses

untukmenemukansuatuaturanhukumgu namenjawabisuhukum yang dihadapi. ${ }^{2}$

\section{PEMBAHASAN \\ C.1. Alasan dibutuhkannya membentuk Memorandum ofUnderstanding dalam melaksanakan sistem pembelajaran berbasis kerjasama di masa pandemi covid-19}

Kerjasama merupakan suatu wujud pengembangan diri dari suatu lembaga termasuk lembaga pendidikan mengingat suatu lembaga pendidikan tidak akan dapat berkembang jika tidak mau membuka diri untuk berinteraksi dengan lembaga lainnya. Lembaga pendidikan yang tidak mau membuka diri untuk berinteraksi dengan lembaga lainnya berakibat pada tidak mampunya mengikuti dan menghadapi perkembangan zaman yang bersifat global dalam dunia pendidikan. Oleh karena itu, kerjasama dibutuhkan oleh lembaga pendidikan terhadap lembaga lainnya demi menjaga maupun

${ }^{2}$ Peter Mahmud Marzuki, 2010,Penelitian Hukum, KencanaPrenada, Jakarta, hlm.35 
Jurnal Hukum Saraswati (JHS) Volume. 03, Nomor 02, (2021)

FAKULTAS HUKUM UNMAS DENPASAR

ISSN (Cetak) : 2715-758X ISSN (Online): 2720-9555

DOI:https://doi.org/10.36733/jhshs.v2i2

https://e-journal.unmas.ac.id/index.php/JHS

meningkatkan kualitas lembaga pendidikan dalam menghadapi perkembangan di dunia pendidikan terutama perkembangan sistem pembelajaran di masa pandemi covid19 yang memaksa seluruh teknis belajar wajib menggunakan media online.

Kerjasama dalam dunia pendidikan merupakan hal yang sudah biasa dilakukan oleh sekolah maupun perguruan tinggi dalam meningkatkan kualitas di bidang pendidikan, penelitian, maupun di bidang pengabdian. Pada masa pandemi covid-19, kerjasama dilakukan tentunya untuk menjaga maupun meningkatkan kualitas terutama di bidang pendidikan terkait pembelajaran dengan inovasi berupa kerjasama dengan lembaga lain dalam memberikan suatu pemahaman kepada peserta didik baik dalam sistem pembelajaran, maupun berupa sosialisasi dengan cara online.

Mekanisme kerjasama mulai dari pembentukan hingga pelaksanaannya jika melihat pada mekanisme perjanjian, secara teoritis dibagi dalam tiga tahap yakni : a. Tahap pracontractual, yaitu adanya penawaran dan penerimaan;

b. Tahap contractual, yaitu adanya persesuaian pernyataan kehendak antara para pihak;

c. Tahap postcontractual, yaitu pelaksanaan perjanjian. ${ }^{3}$

Ilustrasi dari ketiga tahap tersebut pada dasarnya saling berhubungan dalam hal menjelang membentuk kerjasama hingga melaksanakan kerjasama. Dimulai dari tahap pracontractualdimana adanya pengusulan dari salah satu pihak untuk melangsungkan kerjasama hingga selanjutnya para pihak saling melakukan penawaran dan penerimaan dalam usulan melakukan kerjasama. Dalam proses pracontractual, para pihak yang berencana membentuk kerjasama saling mencari titik temu untuk menemukan kesepakatan terhadap segala hal yang nantinya akan diatur dalam kerjasama. Berikutnya pada tahap contractual, para pihak yang telah menemukan kesepakatan

${ }^{3}$ Salim HS., 2016, Pengantar Hukum Perdata Tertulis (BW), Sinar Grafika, Jakarta, h.161. 
Jurnal Hukum Saraswati (JHS) Volume. 03, Nomor 02, (2021)

FAKULTAS HUKUM UNMAS DENPASAR

ISSN (Cetak) : 2715-758X ISSN (Online): 2720-9555

DOI:https://doi.org/10.36733/jhshs.v2i2

https://e-journal.unmas.ac.id/index.php/JHS

98

kemudian membentuk perjanjian pemahaman masyarakat tidak terjadi dengan menuangkan klausul-klausul perbedaan terkait keberadaan dan yang telah disepakati dalam perjanjian. kegunaan

Memorandum begitu pula hingga dilakukan ofUnderstanding $(M o U)$ serta bedanya ceremonyatau suatu acara tentang penandatanganan perjanjian kerjasama tersebut. Perjanjian kerjasama yang telah terbentuk tersebut kemudian dilaksanakan sebagaimana dalam tahap postcontractual.

Persoalan mengenai bentuk kerjasama, biasanya kerjasama dibuat dalam dua bentuk yakni dalam bentuk Memorandum ofUnderstanding ( $M o U)$ maupun dalam bentuk perjanjian. Berbicara mengenai Memorandum ofUnderstanding $(\mathrm{MoU})$ sebagai bentuk atau model kerjasama,munculnya Memorandum ofUnderstanding(MoU) merupakan bentuk kerjasama internasional baik yang bersifat maupun bersifat publik. Dalam hukum nasional meskipun tidak ada pengaturan mengenai Memorandum ofUnderstanding $(\mathrm{MoU}) \quad$ secara spesifik, namun Memorandum ofUnderstanding $(\mathrm{MoU})$ juga biasa digunakan dalam kegiatan kerjasama bisnis maupun kegiatan yang bersifat non bisnis. Oleh karena itu, agar dengan perjanjian, perlu dilakukan suatu regulasi dalam bentuk hukum yang menjelaskan lebih lanjut definisi, kegunaan, serta muatan dari Memorandum ofUnderstanding $(\mathrm{MoU})$.

Dalam lembaga pendidikan juga biasa mempergunakan Memorandum ofUnderstanding $(\mathrm{MoU}) \quad$ sebagai landasan kerjasama baik dalam menjaga maupun meningkatkan kualitas di bidang pendidikan dalam memberikan edukasi kepada masyarakat khususnya terhadap peserta didiknya. Untuk mengetahui alasan mempergunakan

Memorandum ofUnderstanding $(\mathrm{MoU}) \quad$ sebagai landasan kerjasama khususnya dalam hal pengembangan pembelajaran di masa pandemi covid-19, perlu dijelaskan terlebih dahulu secara umum mengenai Memorandum ofUnderstanding $(\mathrm{MoU})$.

Definisi Memorandum ofUnderstanding $(\mathrm{MoU}) \quad$ menurut Munir Fuady sebagai perjanjian pendahuluan yang nanti akan 
Jurnal Hukum Saraswati (JHS) Volume. 03, Nomor 02, (2021)

FAKULTAS HUKUM UNMAS DENPASAR

ISSN (Cetak) : 2715-758X ISSN (Online): 2720-9555

DOI:https://doi.org/10.36733/jhshs.v2i2

https://e-journal.unmas.ac.id/index.php/JHS

99

dijabarkan dan diuraikan dengan perjanjian lainnya yang memuat aturan dan persyaratan secara lebih detail. Sebab itu materi MoU berisi hal-hal yang pokok saja. ${ }^{4}$ Memorandum ofUnderstanding $(\mathrm{MoU}) \quad$ dikenal dengan istilah Nota Kesepahaman. Memorandum of understanding (MoU) merupakan perkembangan baru dalam aspek hukum dalam ekonomi. Pada hakekatnya Memorandum of Understanding merupakan suatu perjanjian pendahuluan yang nantinya akan diikuti dan dijabarkan dalam perjanjian lain yang mengaturnya secara lebih detail. ${ }^{5}$

Memorandum ofUndestanding (MOU) secara idealnya akan dilanjutkan dengan membuat suatu perjanjian. Hanya kadang-kadang oleh karena saling percaya antara para pihak, maka sebuah Memorandum ofUndestanding (MOU) dapat dilaksanakan. Memorandum ofUndestanding (MOU) biasanya baru ditentukan hal-hal yang masih

${ }^{4}$ Burhanuddin $\quad$ S., 2013, Pedoman Penyusunan Memorandum ofUnderstanding (MoU), Medpress Digital, Yogyakarta, h. 7.

${ }^{5}$ Elsi Kartika Sari dan Advendi Simanunsong, 2008, Hukum dalam Ekonomi, Edisi kedua, Grasindo, Jakarta, h. 37. merupakan garis-garis besar dari apa yang disepakati bersama, sedangkan hal-hal yang lebih khusus lagi akan diatur dalam suatu perjanjian tertentu. ${ }^{6}$ Berdasarkan pada beberapa penjelasan mengenai Memorandum ofUnderstanding $(\mathrm{MoU}), \quad$ adapun karakteristik dari Memorandum ofUnderstanding $(\mathrm{MoU})$ antara lain :

1. Memuat tentang peryataan kesediaan untuk saling bekerja sama;

2. Bersifat pendahuluan yang akan diikuti oleh perjanjian lain yang lebih detail;

3. Pada umumya isinya ringkas, bahkan sering sekali hanya memuat satu halaman;

4. MoU hanya berisikan hal-hal pokok yag bersifat umum sebagai ungkapan kesediaan untuk saling bekerja sama;

5. Biasanya tidak ada kewajiban yang bersifat memaksa kepada para pihak untuk membuat suatu perjanjian yang lebih detail;

${ }^{6}$ Samuel M.P. Hutabarat, 2010, Penawaran dan Penerimaan dalam Hukum Perjanjian, Grasindo, Jakarta, h.101. 
Jurnal Hukum Saraswati (JHS) Volume. 03, Nomor 02, (2021)

FAKULTAS HUKUM UNMAS DENPASAR

ISSN (Cetak) : 2715-758X ISSN (Online): 2720-9555

DOI:https://doi.org/10.36733/jhshs.v2i2

https://e-journal.unmas.ac.id/index.php/JHS

100

6. Sifatnya sementara hingga dalam melaksanakan suatu hal. jangka waktu tertentu yang Mengingat Memorandum apabila tidak ditindaklanjuti ofUnderstanding $(\mathrm{MoU})$ merupakan dalam bentuk perjanjian, kesepakatan awal, maka Memorandum maka MoU akan batal ofUnderstanding $(\mathrm{MoU})$ tidak dibuat dengan sendirinya. Apabila secara terperinci mengenai mekanisme dikehendaki, masa berlaku pelaksanaan suatu hal. Oleh karena MoU dapat diperpanjang;

Memorandum ofUnderstanding(MoU)

7. Biasanya tidak ada kewajiban yang bersifat memaksa tidak merinci pelaksanaan suatu hal, maka

Memorandum kepada para pihak untuk ofUnderstanding $(\mathrm{MoU})$ hanyalah suatu membuat suatu perjanjian yang lebih detail setelah penandatanganan $\mathrm{MoU}$;

8. Tidak menekankan berlakunya sanksi hukum kepada masing-masing pihak;

9. MoU biasanya dibuat dalam bentuk perjanjian di bawah tangan. $^{7}$

Berdasarkan pada definisi dan karakteristik Memorandum ofUnderstanding $(\mathrm{MoU})$, maka dapat dipahami bahwa Memorandum ofUnderstanding $(\mathrm{MoU}) \quad$ hanyalah kesepakatan awal yang terjalin antara para pihak dalam arti para pihak bersedia untuk saling mengikatkan diri

${ }^{7}$ Burhanuddin $\quad$ S., 2013, Pedoman Penyusunan Memorandum ofUnderstanding (MoU), Medpress Digital, Yogyakarta, h. 16.

kesepakatan awal yang digunakan sebagai dasar dalam melaksanakan suatu hal yang ditindaklanjuti kemudian dengan perjanjian baik itu perjanjian dalam bentuk tertulis maupun perjanjian lisan, yang mengatur secara rinci terkait pelaksanaan suatu hal baik terkait hak, kewajiban, kompensasi, dan lain sebagainya. Berdasarkan hal tersebut, maka dalam tatanan Memorandum ofUnderstanding $(\mathrm{MoU})$, tidak ada istilah wanprestasi karena belum mengatur segala hal mengenai pelaksanaan kesepakatan secara terperinci, sehingga jika ada permasalahan hanyalah dapat menyelesaikan dengan cara bermusyawarah. 
Jurnal Hukum Saraswati (JHS) Volume. 03, Nomor 02, (2021)

FAKULTAS HUKUM UNMAS DENPASAR

ISSN (Cetak) : 2715-758X ISSN (Online): 2720-9555

DOI:https://doi.org/10.36733/jhshs.v2i2

https://e-journal.unmas.ac.id/index.php/JHS

101

\section{Memorandum ofUnderstanding} sebagai kesepakatan awal memiliki keunggulan yakni bentuknya simpel dan sifatnya fleksibel dengan menyesuaikan keadaan dalam melaksanakan suatu kerjasama, hanya saja kekurangannya adalah tidak mengikat para pihak tegas dalam melaksanakan suatu hal karena tidak diatur secara terperinci pelaksanaan suatu hal yang diperjanjikan, hak, kewajiban, dan lain sebagainya. jadi pada dasarnya Memorandum ofUnderstanding (MoU) hanyalah sebagai dasar untuk mengikat keseriusan para pihak yang nantinya ditindaklanjuti dengan perjanjian tertentu baik tertulis maupun lisan terhadap pelaksanaan suatu hal yang disepakati. Berbeda halnya dengan perjanjian yang mengatur secara tegas dan terperinci mengenai segala hal yang disepakati dalam perjanjian.

Berdasarkan pada penjelasan mengenai Memorandum ofUnderstanding (MoU), maka sudah jelas bahwa Memorandum ofUnderstanding (MoU) merupakan bentuk landasan kerjasama yang tepat jika digunakan terutama bagi lembaga pendidikan menjalin kerjasama dengan lembaga lainnya untuk melakukan pengembangan sistem pembelajaran berbasis kerjasama melalui media online di masa pandemi covid-19. Pembelajaran berbasis kerjasama ini dilakukan dengan mengundang narasumber dari lembaga lain dalam memberikan edukasi kepada peserta didik, misalnya dalam mata kuliah praktek acara perdata mengundang Hakim dari lembaga Peradilan untuk memberikan kuliah umum mengenai teknis beracara.

Sistem kerjasama dengan menggunakan Memorandum ofUnderstanding (MoU) dapat dipilih sebagai landasan kerjasama mengingat bentuknya simpel karena muatannya hanyalah kesepakatan awal dari pihak yang pelaksanaan secara terperinci dari kesepakatan itu dikomunikasikan atau diperjanjikan kemudian oleh para pihak dalam perjanjian tertulis ataupun lisan. Jika menggunakan Memorandum ofUnderstandingatau Nota Kesepahaman terkait sistem pembelajaran berbasis kerjasama secara online di masa pandemi covid19, maka pelaksanaanya tergantung 
Jurnal Hukum Saraswati (JHS) Volume. 03, Nomor 02, (2021)

FAKULTAS HUKUM UNMAS DENPASAR

ISSN (Cetak) : 2715-758X ISSN (Online): 2720-9555

DOI:https://doi.org/10.36733/jhshs.v2i2

https://e-journal.unmas.ac.id/index.php/JHS

102

kemudian pada komunikasi lembaga penyelenggara pendidikan dengan lembaga yang diajak sebagai narasumber perihal siapa yang dikirim menjadi narasumber, kesediaan menjadi narasumber, jangka waktu mengisi materi, teknis pembelajaran online yang dilakukan oleh narasumber, materi yang disampaikan oleh narasumber, maupun hal-hal lain yang terkait dengan sistem pembelajaran yang melibatkan narasumber tersebut. Oleh karena itu, pelaksanaan dari Memorandum ofUnderstanding (MoU) ini bersifat fleksibel karena menyesuaikan dengan kesepakatan para pihak mengenai teknis pelaksanaannya.

\section{C.2. Metode}

menyusunMemorandum

ofUnderstandingsebagaidasarh

ukumbekerjasamamelaksanak anpembelajarandi masa pandemi covid-19.

Menyusun

Memorandum

ofUnderstanding (MoU) terutama bagi lembaga pendidikan untuk menjadi dasar hukum melaksanakan strategi pengembangan pembelajaran di masa pandemi

covid-19

tentunya membutuhkan pengetahuan mengenai susunan isi dari Memorandum ofUnderstanding (MoU). Perlu diketahui bahwa Memorandum ofUnderstanding (MoU) atau nota kesepahaman merupakan persesuaian kehendak yang dinyatakan secara tertulis antara para pihak untuk membangun hubungan hukum seperti halnya hubungan kerjasama. Bentuk Memorandum ofUnderstanding (MoU) atau nota kesepahaman pada dasarnya dibuat tertulis. Isi dari Memorandum ofUnderstanding (MoU) atau Nota Kesepahaman tidak membuat secara terperinci mengenai mekanisme pelaksanaannya.

Berkenaan dengan isi Memorandum of Understanding (MoU), ketika menyusun Memorandum ofUnderstanding (MoU) perlu memiliki pemahaman mengenai anatomi dari Memorandum ofUnderstanding (MoU). Jika berbicara anatomi penyusunan Memorandum ofUnderstanding, hingga saat initidak terdapat mengenai format bakunya. Praktek penyusunan Memorandum ofUnderstanding (MoU) 
Jurnal Hukum Saraswati (JHS) Volume. 03, Nomor 02, (2021)

FAKULTAS HUKUM UNMAS DENPASAR

ISSN (Cetak) : 2715-758X ISSN (Online): 2720-9555

DOI:https://doi.org/10.36733/jhshs.v2i2

https://e-journal.unmas.ac.id/index.php/JHS

103

biasanya dapat pula merujuk pada anatomi perjanjian, hanya saja isinya tidak seperti perjanjian yang mengatur hak dan kewajiban secara terperinci, melainkan hanya berisikan pernyataan bahwa para pihak sepakat untuk menjalin hubungan hukum terutama dalam bekerjasama melaksanakan pembelajaran di masa pandemi covid19. Oleh karena itu, sebagaimana merujuk pada anatomi perjanjian, maka susunan Memorandum ofUnderstanding (MoU) sekurangkurangnya berisi :

1. Judul

Pada umumnya judul harus dibuat secara singkat, jelas, dan menggambarkan keseluruhan perjanjian. Untuk pembuatan judul, pada perjanjian umumnya dibuat dengan ringkas seperti : PERJANJIAN SEWA MENYEWA atau PERJANJIAN PENGADAAN ALAT TULIS PERKANTORAN, sedangkan Memorandum ofUnderstanding, judulnya dapat dibuat dengan contoh berikut :

NOTA KESEPAHAMAN

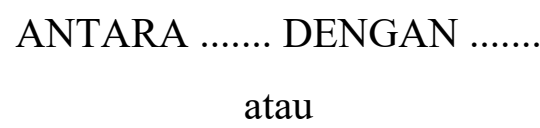

\section{NOTA KESEPAKATAN}

KERJA SAMA PROGRAM .......

\section{Pembukaan}

Kalimat pembukaan umumnya dibuat dengan menunjukkan tanggal maupun tempat terjadinya perjanjian maupun

Memorandum ofUnderstanding. Misalnya seperti berikut :

- Pada hari ini, Kamis, tanggal 18 Juni 2020, Kami yang bertandatangan di bawah ini

- Pada hari ini, Kamis, tanggal 18 Juni 2020, bertempat di Denpasar, Kami yang bertandatangan di bawah ini

\section{Komparisi}

Bagian Komparisi biasanya menyebutkan identitas para pihak termasuk pula menjelaskan kedudukan dan kewenangan para pihak. misalnya seperti berikut :

Nama : Dr. Andi Hardian, S.H.,M.H.

Pekerjaan / Jabatan : Ketua Pengadilan Negeri .......

Alamat : J1. 
Jurnal Hukum Saraswati (JHS) Volume. 03, Nomor 02, (2021)

FAKULTAS HUKUM UNMAS DENPASAR

ISSN (Cetak) : 2715-758X ISSN (Online): 2720-9555

DOI:https://doi.org/10.36733/jhshs.v2i2

https://e-journal.unmas.ac.id/index.php/JHS

104

Selanjutnya disebut sebagai

PIHAK PERTAMA.

Atau

Perbedaan antara Memorandum ofUnderstanding (MoU) dengan Perjanjian biassanya terlihat pada

Dr. Andi Hardian, S.H.,M.H., bagian isi. Jika dalam bentuk

Ketua Pengadilan Negeri perjanjian, mencantumkan secara jelas, yang beralamat di J Selanjutnya disebut sebagai

\section{PIHAK PERTAMA}

4. Premise

Pada dasarnya premise berisi maksud dan tujuan dari para pihak, termasuk dalam melakukan suatu perjanjian. misalnya seperti berikut :

- Bahwa para pihak sepakat mengadakan kerjasama dengan maksud untuk melakukan pengembangan di bidang "Pendidikan" dengan ketentuan yang disepakati sebagai berikut :

\section{Atau}

- Bahwa dalam rangka pengembangan

"Pendidikan", para pihak sepakat mengadakan

kerjasama dengan ketentuan sebagai berikut :

5. Isi kontrak lengkap, dan detail mengenai hak, kewajiban, maupun objek perjanjian, berbeda halnya dengan Memorandum ofUnderstandingyang biasanya tidak menjelaskan mengenai hak, kewajiban, maupun objek perjanjian dengan lengkap dan detail mengingat Memorandum

ofUnderstandinghanyalah kesepakatan prakontrak yang mengikat kehendak para pihak untuk menjalin suatu hubungan hukum. Memorandum ofUnderstanding (MoU) meskipun tidak mengatur secara lengkap dan detail mengenai isi kesepakatan, namun isi kesepakatan dalam Memorandum ofUnderstanding (MoU) tentunya menjadi pedoman dalam melaksanakan hal-hal yang disepakati dengan menindaklanjutinya dengan perjanjian baik tertulis maupun lisan. Adapun contoh dari isi Memorandum ofUnderstanding sebagai berikut :

PASAL 1

RUANG LINGKUP 
Jurnal Hukum Saraswati (JHS) Volume. 03, Nomor 02, (2021)

FAKULTAS HUKUM UNMAS DENPASAR

ISSN (Cetak) : 2715-758X ISSN (Online): 2720-9555

DOI:https://doi.org/10.36733/jhshs.v2i2

https://e-journal.unmas.ac.id/index.php/JHS

105

Ruang lingkup Nota Kesepahaman ini adalah untuk melakukan program kerjasama di bidang pendidikan

khususnya melalui kegiatan Kuliah

Umum secara online.

PASAL 2

\section{HAK DAN KEWAJIBAN}

a. Pihak KEDUA wajib untuk melakukan kordinasi dalam melaksanakan kerjasama Kuliah Umum dengan Pihak PERTAMA;

b. Pihak PERTAMA wajib untuk melakukan kordinasi saat mengirimkan narasumber dalam pelaksanaan kerjasama Kuliah Umum dengan Pihak KEDUA.

\section{PASAL 3}

JANGKA WAKTU

a. Nota Kesepahaman ini berlaku selama 2 (dua) tahun sejak Nota Kesepahaman ini ditandatangani;

b. Nota Kesepahaman ini dapat diperpanjang sesuai dengan kesepakatan para pihak.

Memperhatikan pada contoh isi Memorandum ofUnderstanding $(M o U), \quad$ isinya tidaklah sebanyak perjanjian yang mengatur secara detail teknis pelaksanaan perjanjiannya termasuk sanksi bila terjadi pelanggaran. Pada dasarnya isi dari Memorandum ofUnderstanding (MoU) dibuat secara singkat dan jelas dan tidak menjelaskan secara detail teknis pelaksanaannya. Isi secara garis besar Memorandum ofUnderstanding (MoU) hanyalah kesepahaman para pihak untuk melakukan sesuatu kegiatan seperti pada contoh terkait melaksanakan kerjasama dalam melakukan pembelajaran di masa pandemi covid-19, yang pelaksanaannya dikordinasikan atau diperjanjikan kemudian.

\section{Exceptclause}

Pada bagian exceptclausedidalamnya berisi penjabaran terhadap hal-hal yang tidak dikehendaki seperti wanprestasi, forcemajeur, maupun penyelesaian sengketa. Penyelesaian sengketa pada perjanjian biasanya pula dicantumkan dengan jelas dengan menunjuk Pengadilan mana yang digunakan sebagai lembaga penyelesaian sengketa. Berbeda halnya dengan Memorandum ofUnderstanding, yang 
Jurnal Hukum Saraswati (JHS) Volume. 03, Nomor 02, (2021)

FAKULTAS HUKUM UNMAS DENPASAR

ISSN (Cetak) : 2715-758X ISSN (Online): 2720-9555

DOI:https://doi.org/10.36733/jhshs.v2i2

https://e-journal.unmas.ac.id/index.php/JHS

106

biasanya dibuat penyelesaian

permasalahan akan diselesaikan

dengan perundingan bersama. Adapun

contoh dari exceptclause sebagai

berikut :

PASAL 4

PENYELESAIAN

PERMASALAHAN

a. Tidak ada pihak dalam Nota Kesepahaman ini yang dapat disebut wanprestasi

b. Apabila ada permasalahan yang timbul antara kedua belah pihak karena Nota Kesepahaman ini, diutamakan penyelesaiannya dengan musyawarah mufakat secara kekeluargaan.

\section{Penutup}

Pada bagian terakhir yakni bagian penutup, umumnya bagian penutup memuat tentang kalimat penutup, para pihak yang menandatangani perjanjian, maupun saksi-saksi yang terlibat didalamnya. Untuk kalimat penutup pada Memorandum ofUnderstanding pada umumnya sama dengan membuat kalimat penutup pada perjanjian. Adapun contoh kalimat penutup sebagai berikut :

\section{PASAL 5}

PENUTUP

Nota Kesepahaman ini dibuat dan ditandatangani oleh kedua belah pihak dalam rangkap dua dengan bermaterai secukupnya serta mempunyai kekuatan hukum yang sama.

\section{PENUTUP}

\section{D.1. Kesimpulan}

Memorandum

ofUnderstandingatau

Nota

Kesepahaman dapat digunakan oleh lembaga pendidikan dalam menyelenggarakan sistem pembelajaran online berbasis kerjasama di masa pandemi covid-19 dengan mengundang narasumber dari lembaga lain. Hanya saja karena Memorandum ofUnderstandingatau Nota Kesepahaman merupakan pernyataan tertulis para pihak yang bersifat kesepakatan awal, maka pelaksanaannya perlu dikomunikasikan oleh para pihak mengenai teknisnya.

Berkenaan dengan metode menyusun Memorandum ofUnderstandingatau Nota Kesepahaman, anatominya kurang lebih sama dengan perjanjian, hanya 
Jurnal Hukum Saraswati (JHS) Volume. 03, Nomor 02, (2021)

FAKULTAS HUKUM UNMAS DENPASAR

ISSN (Cetak) : 2715-758X ISSN (Online): 2720-9555

DOI:https://doi.org/10.36733/jhshs.v2i2

https://e-journal.unmas.ac.id/index.php/JHS

saja tidak mengatur secara rinci teknis

pelaksanaannya, persoalan hak dan

kewajiban, termasuk tidak ada sanksi

yang ditetapkan jika Memorandum

ofUnderstandingatau

Nota

Kesepahaman belum dilaksanakan.

\section{D.2. Saran}

Perlu dilakukan suatu sosialisasi atau pelatihan mengenai penyusunan Memorandum ofUnderstanding (MoU) di lembaga pendidikan terutama dalam pelaksanaan pembelajaran untuk memberikan edukasi mengenai teknis menyusun Memorandum ofUnderstanding (MoU), serta manfaat menggunakan Memorandum ofUnderstanding (MoU) sebagai landasan kerjasama.

\section{DAFTAR PUSTAKA}

\section{BUKU}

Burhanuddin S., 2013, Pedoman Penyusunan Memorandum ofUnderstanding (MoU), Medpress Digital, Yogyakarta.

Hutabarat, Samuel M.P., 2010, Penawaran dan Penerimaan dalam Hukum Perjanjian, Grasindo, Jakarta.
R. Gilang K. , 2020, Pelaksanaan Pembelajaran Daring di Era Covid-19, Lutfi Gilang, Banyumas.

Salim HS., 2016, Pengantar Hukum Perdata Tertulis $(B W)$, Sinar Grafika, Jakarta.

Sari, Elsi Kartika dan Advendi Simanunsong, 2008, Hukum dalam Ekonomi, Edisi kedua, Grasindo, Jakarta. 